\title{
Examination of $\mathrm{CO}_{2}$ emission of different stubbles on a chernozem soil
}

\author{
Györgyi Kovács \\ Karcag Research Institute of University of Debrecen CAAES RIEF, 5300 Kisújszállási Str. 166. Karcag, \\ kovacsgyorgyi@agr.unideb.hu
}

\begin{abstract}
Applying alternative soil cultivation methods based on reduced disturbance of the soil more favourable conditions can be created in order to increase the organic matter content of the soil and the availability of the nutrients for the crops. In complex soil tillage experiment - in 1997 was set on - at Karcag, as the element of the investigation of soil reduced and conventional tillage systems. There is close correlation between the degree and intensity of $\mathrm{CO}_{2}$-emission from the soil and the structural state and organic matter content of the soil. In order to quantify the increased $\mathrm{CO}_{2}$-emission from soil due to soil preserving cultivation systems, in situ $\mathrm{CO}_{2}$-emission of soil was measured by means of an ANAGAS 98 infrared gas analyser. The soil type of the investigated plot is meadow chernozem solonetz in the deeper layers, a soil type that is characteristic for the Trans-Tisza Region of Hungary. In this paper the results gained from the measurement on different stubbles are published, as we consider stubbles the most suitable state when the effects of different soil cultivation systems on the microbiological activity of the soil can be compared. Experimental data provided information about the length of the time period when $\mathrm{CO}_{2}$ emission increasing effects of soil cultivation are observable. Studying the effect of different soil cultivation methods on the $\mathrm{CO}_{2}$ emission from chernozem soil is indisputably actual and needs more efforts as it can contribute to develop a more environmental friendly agricultural production. The main goal of these measurements was to determine the effect of soil cultivation technologies and certain agrotechnical elements on the factors of the soil carbon cycle.
\end{abstract}

Keywords: $\mathrm{CO}_{2}$ emission, chernozem soil, stubbles

\section{Introduction}

Soil is the main source and at the same time the potential sink of greenhouse gases (e.g. $\mathrm{CO}_{2}$, $\mathrm{CH}_{4}$ ). The carbon-dioxide gas emitted from the soil mainly originates from root respiration, microbiological activity and decomposition of organic matters. The volume and intensity of $\mathrm{CO}_{2}$-emission is in close correlation to the structural state and organic content of the soil, hence it can be considered as a parameter of soil fertility. Measuring $\mathrm{CO}_{2}$-emission, the most important (from agricultural point of view) characteristic of the soil can be directly quantified. As the practice of soil cultivation is changing in Hungary nowadays, consequently soil properties also change that results in the change of the microbiological activity, nutrient dynamics and organic matter profile of the soil (Zsigrai, 2001). All these have a great influence on plant production. The process of $\mathrm{CO}_{2}$-circulation between the soil and the atmosphere is very changeable in time and space, getting more information on it could contribute to the correct assessment of the microbiological activity corresponding to the actual soil state. The main goal of these measurements was to determine the effect of soil cultivation technologies and certain agrotechnical elements on the factors of the soil carbon cycle.

Among the land use practices the soil cultivation has the most radical effects on soil properties. The need for environmental friendly and energy saving soil tillage systems is increasing as the consequences of improper soil cultivation practice that characterised the last decades are manifested in unfavourable soil properties (Birkás et al., 2007). Aspect of soil protection is very important to change conventional tillage - based on twill - to reduced tillage that is suitable for our climate and soil conditions (Nyíri, 1997). Agrotechnical methods indirectly increase $\mathrm{CO}_{2}$ emission of the soil. Indirect processes like soil degradation (water- and wind erosion), land drainage are resources of carbon mobilisation.

The carbon balance of terrestrial ecosystems can be changed markedly by the direct impact of human activities-including deforestation, biomass burning, land use change, and environmental pollution, which release trace gases that enhance the 'greenhouse effect' (Bolin, 1981; Trabalka - Reichle, 1986). 
The advanteges of the alternative tillage systems are the better energy consumption, the low mechanical inputs thus dwindle $\mathrm{CO}$ and $\mathrm{CO}_{2}$ emission. In addition, biodiversity grows, soil structure, soil porosity, adsorption capacity are gravelled and appropriate water management. Soil compaction rarely occurs because of the lower mechanical inputs. Soil surface is covered by plant residues, so erosion is avoided and organic matters are kept in the soil. Organic matters have significant affect on soil structure, buffer capacity, water retention ability, biological activity and nutrient equilibrium (Holland, 2004).

The aim of this experiment is to get information about $\mathrm{CO}_{2}$ cycle at variant soil, cultivation and climate conditions in cropland on a chernozem soil..

\section{Materials and methods}

The $\mathrm{CO}_{2}$-emission measurements were carried out at the Karcag Research Institute of University of Debrecen, Centre for Agricultural and Applied Economic Sciences (KRI). The Institute has been dealing with a complex soil cultivation experiment. This complex soil tillage experiment (H-1) was set on 15.8 ha in 1997 with conventionally cultivated (plough based) plots, with reduced tillage treatments respectively. The main goal of this research is to reveal the processes that result in the emission of $\mathrm{CO}_{2}$ from the soil into the atmosphere (Zsembeli-Kovács, 2007). Crop rotation characteristic for the region is used (wheat or barley, maize, sunflower, peas or chickling vetch).

The soil type of the investigated plot is meadow chernozem solonetzic in the deeper layers, a soil type that is characteristic for the Trans-Tisza Region of Hungary. The parent marterial: "infusion loess". Table 1-2 shows the chemical and physical properties of the soil.

Table 1: Some chemical properties of the soil

\begin{tabular}{|c|c|c|c|c|c|c|}
\hline $\begin{array}{c}\text { Genetic } \\
\text { layer }\end{array}$ & $\mathrm{pH}\left(\mathrm{H}_{2} \mathrm{O}\right)$ & $\mathrm{y}_{1}$ & $\begin{array}{c}\mathrm{CaCO}_{3} \\
\%\end{array}$ & $\begin{array}{c}\mathrm{Na}_{2} \mathrm{CO}_{3} \\
\%\end{array}$ & $\sum$ Salt $\%$ & $\begin{array}{c}\text { Humus } \\
\%\end{array}$ \\
\hline $\mathrm{A}_{\mathrm{sz}}$ & 6,3 & 15,2 & 0 & 0 & 0,04 & 2,68 \\
\hline$A_{1}$ & 7,5 & 8,0 & 0 & 0 & 0,04 & 2,27 \\
\hline B & 8,5 & 0 & 6,9 & 0,026 & 0,04 & 1,67 \\
\hline $\mathrm{BC}$ & 8,6 & 0 & 12,3 & 0,056 & 0,04 & 1,18 \\
\hline $\mathrm{C}$ & 8,7 & 0 & 14,4 & 0,051 & 0,04 & 1,18 \\
\hline
\end{tabular}


Table 2: Some physical properties of the soil

\begin{tabular}{|c|c|c|c|c|c|c|}
\hline \multirow{2}{*}{$\begin{array}{c}\text { Genetic } \\
\text { layer }\end{array}$} & \multicolumn{4}{|c|}{ Moisture content $\left(\mathrm{v} \mathrm{v}^{-1} \%\right)$} & \multirow{2}{*}{$\begin{array}{c}\text { Bulk Density } \\
\left(\mathrm{g} \mathrm{cm}^{-3}\right)\end{array}$} & \multirow{2}{*}{$\mathrm{K}_{\mathrm{A}}{ }^{*}$} \\
\cline { 2 - 5 } & $\mathrm{pF} \mathrm{0}$ & $\mathrm{pF} \mathrm{0,4}$ & $\mathrm{pF} 2$ & $\mathrm{pF} 2,4$ & 1,59 & 45 \\
\hline $\mathrm{A}_{\mathrm{sz}}$ & 41,87 & 40,76 & 36,91 & 33,82 & 1,56 & 47 \\
\hline $\mathrm{A}_{1}$ & 42,57 & 40,73 & 35,57 & 33,19 & 1,28 & 50 \\
\hline $\mathrm{B}$ & 52,03 & 49,14 & 36,22 & 31,22 & 1,31 & 52 \\
\hline $\mathrm{BC}$ & 51,89 & 50,01 & 35,69 & 30,61 & 1,37 & 55 \\
\hline $\mathrm{C}$ & 46,90 & 45,82 & 35,11 & 30,31 & & \\
\hline
\end{tabular}

* Plasticity according to Arany (MSZ-08-0205:1978 5.1)

The plots of this experiment provide good opportunity to measure the $\mathrm{CO}_{2}$-emission from the soil. One fraction of this complex approach is measuring the $\mathrm{CO}_{2}$-emission from soil. It is obvious if less fuel is consumed, the load of greenhouse gases to the atmosphereis also less, but at the same time it is said that soil conservation tillage techniques usually result in increased $\mathrm{CO}_{2}$-emission from soil (Gyuricza, 2000). In order to quantify this, in situ $\mathrm{CO}_{2}-$ emission of soil was measured by means of an ANAGAS 98 infrared gas analyser (Fig. 1.).

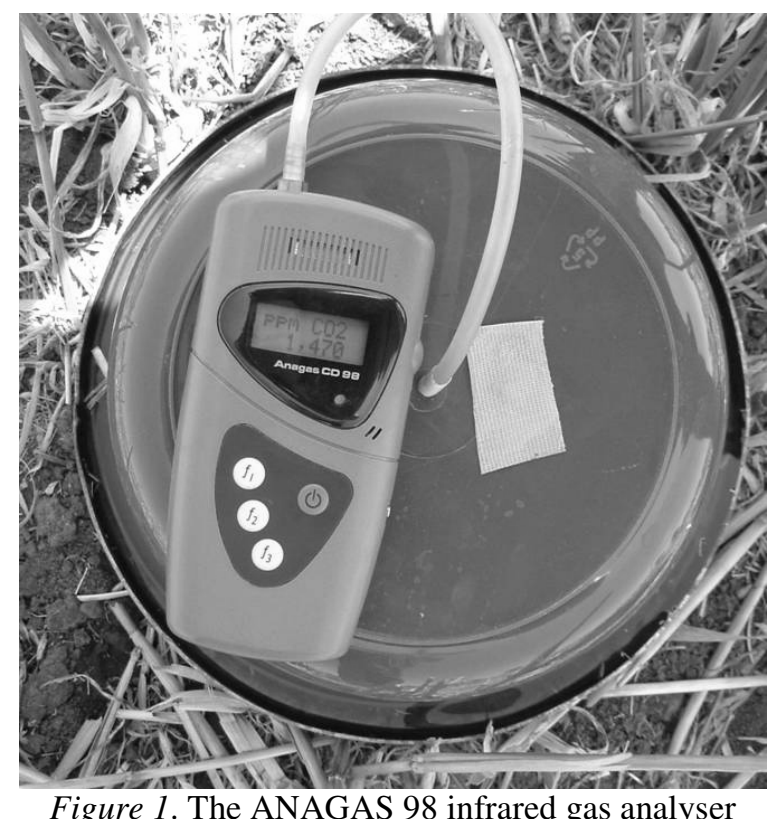

Special, individually developed sets were used consisting of a metal frame and a plastic bowl each (Zsembeli et al., 2006). In order to have perfect isolation, the metal frame is inserted into the soil (sharpened bottom edge) down to $5.5 \mathrm{~cm}$ and the trough around the frame is filled with water. The volume of the plastic bowls is approximately $4000 \mathrm{~cm}^{3}$, the diameter of the metal frames is $20 \mathrm{~cm}$. (Fig. 2.). 


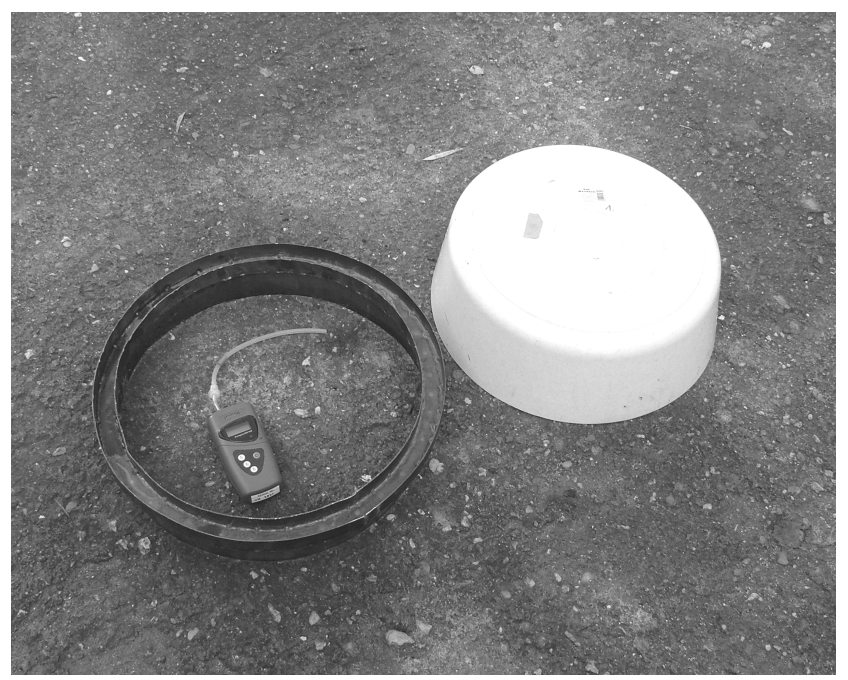

Figure 2. The frame+bowl method

To calculate $\mathrm{CO}_{2}$-emission from soil the following formula was used:

$$
\mathrm{F}=\mathrm{d} *(\mathrm{~V} / \mathrm{A}) *(\mathrm{C} 2-\mathrm{C} 1) / \mathrm{t} * 273 /(273+\mathrm{T})
$$

where F: $\mathrm{CO}_{2}$-flux $\left(\mathrm{kg} \mathrm{m}^{-2} \mathrm{~s}^{-1}\right)$, d: density of $\mathrm{CO}_{2}\left(\mathrm{~kg} \mathrm{~m}^{-3}, 1.96\right.$ for $\left.\mathrm{CO}_{2}\right)$, V: volume of head space of chamber $\left(\mathrm{m}^{3}\right), A$ : area of chamber $\left(\mathrm{m}^{2}\right), \mathrm{C}_{1}: \mathrm{CO}_{2}$-concentration at time of start $\left(\mathrm{m}^{3}\right.$ $\left.\mathrm{m}^{-3}\right), \mathrm{C}_{2}: \mathrm{CO}_{2}$-concentration at time of end $\left(\mathrm{m}^{3} \mathrm{~m}^{-3}\right), \mathrm{t}$ : duration of measurement (s), $\mathrm{T}$ : air temperature $\left(\mathrm{C}^{\circ}\right)$.

In this paper the results gained from the measurement on stubbles are published, as we consider stubbles the most suitable state when the effects of different soil cultivation systems on the microbiological activity of the soil can be compared. In stubble state, obviously after the harvest of the crop), root respiration is not characteristic, therefore the carbon-dioxide gas emitted from the soil is purely due to the microbiological activity, so more precise comparisons can be done.

\section{Results and discussion}

In 2007 we determined $\mathrm{CO}_{2}$-emission on stubbles of early harvested crop (rape) in June and August. The highest carbon-dioxide emission degrees were calculated in conventional tillage plots instead of plots of reduced tillage systems. In line with higher air thermal, $\mathrm{CO}_{2}$ emission of the soil was growing too. In addition cultivation differences were shown as well. The data of four measurement dates are indicated, these four measurements were carried out between the middle of June and middle of July, a one-month-long period directly following the sowing of millet. Our goal involved the determination of the differences due to the treatments as well as the duration of their effect. As the microbiological activity of the soil, hence its $\mathrm{CO}_{2}$ emission are in strong correlation to the moisture content of the soil, we took the amount of precipitation fallen in the investigated period into consideration. In June, before the start of the measurements, $12.8 \mathrm{~mm}$ of rainfall was detected, between the first and the second measurements $18.9 \mathrm{~mm}$, while $9.5 \mathrm{~mm}$ and $33 \mathrm{~mm}$ between the second and the third and between the last two ones respectively. These amounts, which are considered high in the summer period, ensured the relatively high values of $\mathrm{CO}_{2}$-emission along the investigated period. In earlier set on long term cultivation experiment $(\mathrm{H}-1)$ higher $\mathrm{CO}_{2}$ emissions were calculated than it used to (Figure 3.). Reasons of this strange result are investigated. There wasn't remarkable difference between the crop yields in variant cultivating plots but in ploughed plot were bigger root weigh and deeper root development. The case of conventional 
tillage all the crop residues were baled and removed from the subplot so it could be influential factor.

Our data, gained in other experiments previously, showed that in dry periods the $\mathrm{CO}_{2}$ emission increasing effect of different soil cultivation operations lasts 6-10 days only. This duration is in correspondence with the literature data (Franzlubberz et al., 2000; Fieber and Schiemel, 2003).

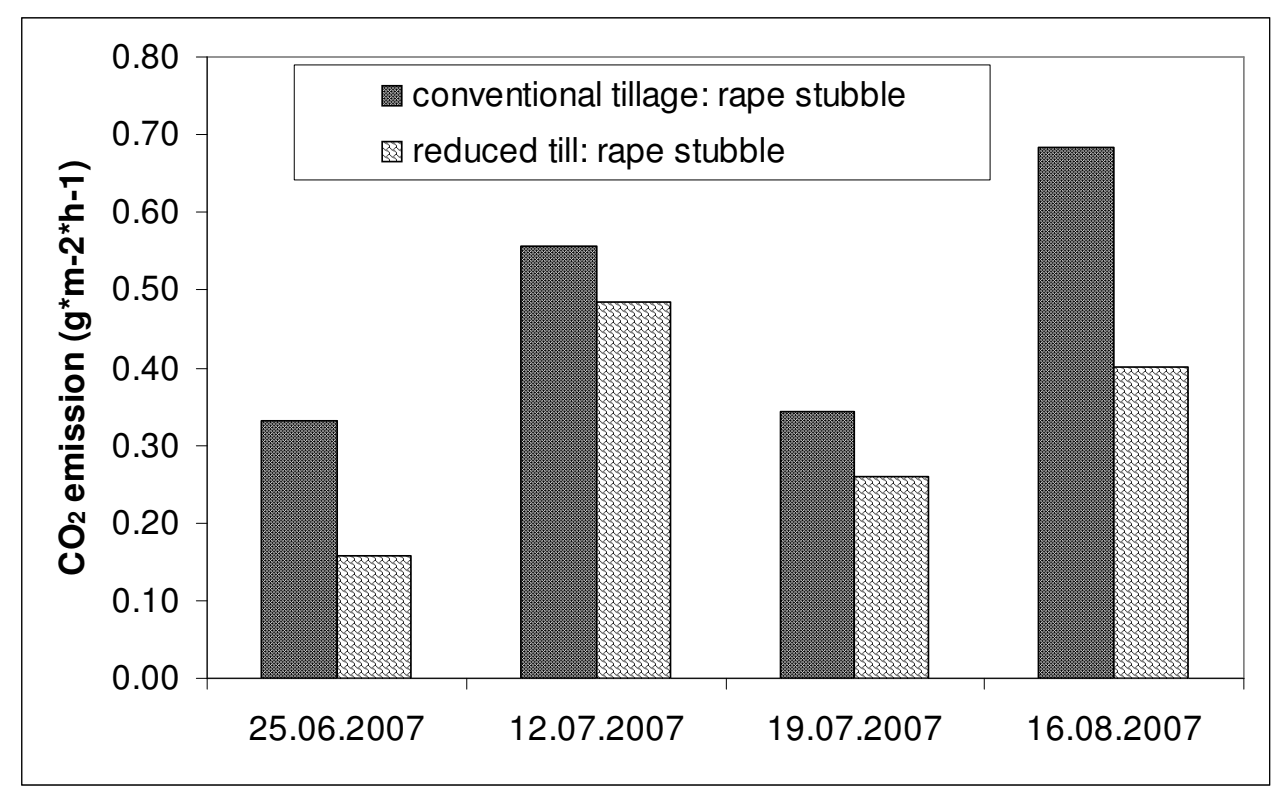

Figure 3. $\mathrm{CO}_{2}$-emission values in the soil tillage experiment in 2007

In 2008 we had four opportunities to measure $\mathrm{CO}_{2}$-emission in the soil tillage experiment. The results we gained are summarised in Fig. 4. We compared the values measured in the conventionally cultivated plots to direct seeding In accordance with the literature, all the tillage operations induced increased $\mathrm{CO}_{2}$-emission. The highest values were detected in the case of the conventionally cultivated, in other words ploughed plot, and this highest value was characteristic all along the investigated period. This was an unexpected result as reduced tillage is considered to be resulted in higher emission. Of course the shortness of the investigated period and the high amount of precipitation can not let us to conclude general conclusions, but there is no doubt that we gained remarkable results about the correlation between the soil status and the $\mathrm{CO}_{2}$-emission from the soil. 


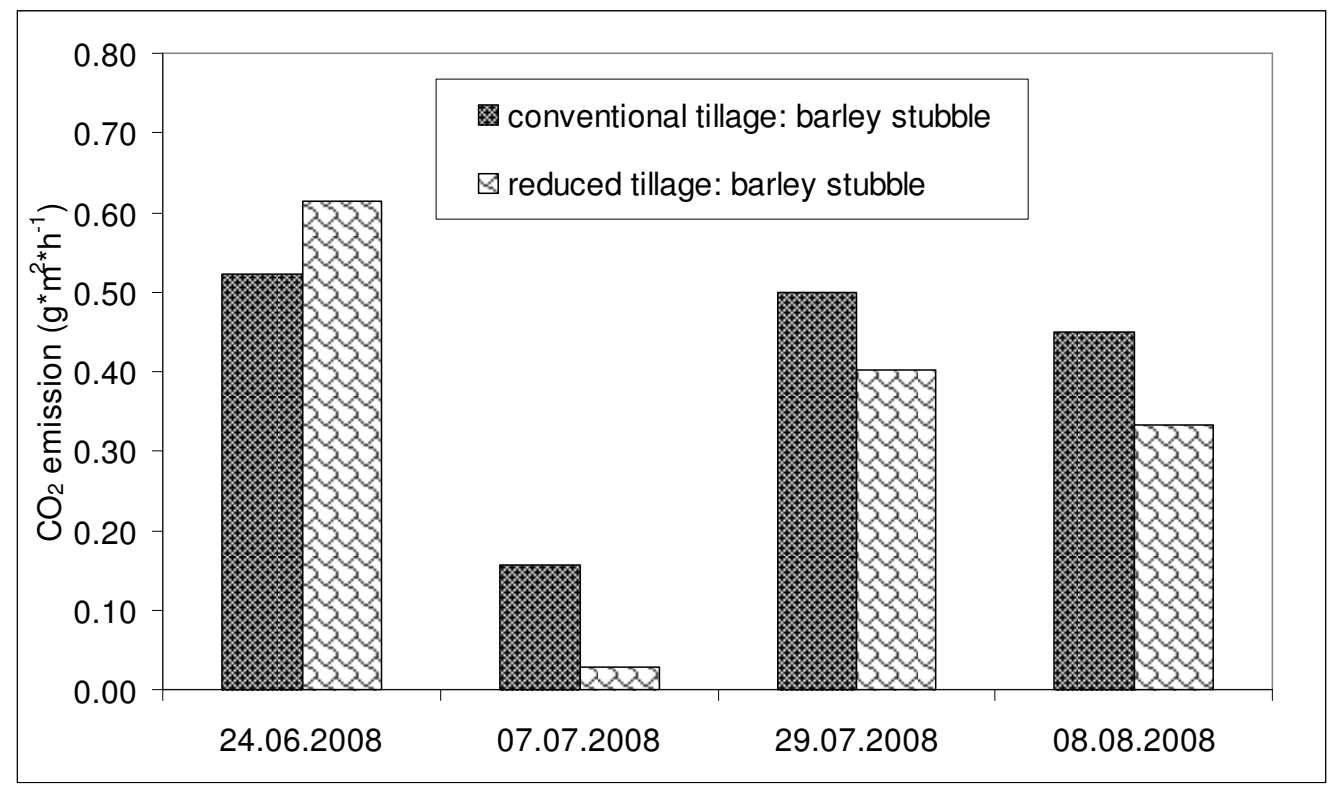

Figure 4. $\mathrm{CO}_{2}$-emission values in the soil tillage experiment in 2008

Fig. 5. shows the $\mathrm{CO}_{2}$-emission values determined for the treatments of the soil tillage experiment in 2009. Three measurement dates are indicated, the first measurement was done after the harvest and before the relevant tillage application. In July, which was very dry in 2009, higher emission was detected in the reduce tillage system. In August the measurements were done after tillage application.. This period was very dry that could explain the very low $\mathrm{CO}_{2}$-emission values. The meteorological conditions and so the emission levels were similar in September. Of course the shortness of the investigated period can not let us to conclude general conclusions, but there is no doubt that we gained remarkable results about the correlation between the soil status and the $\mathrm{CO}_{2}$-emission from the soil.

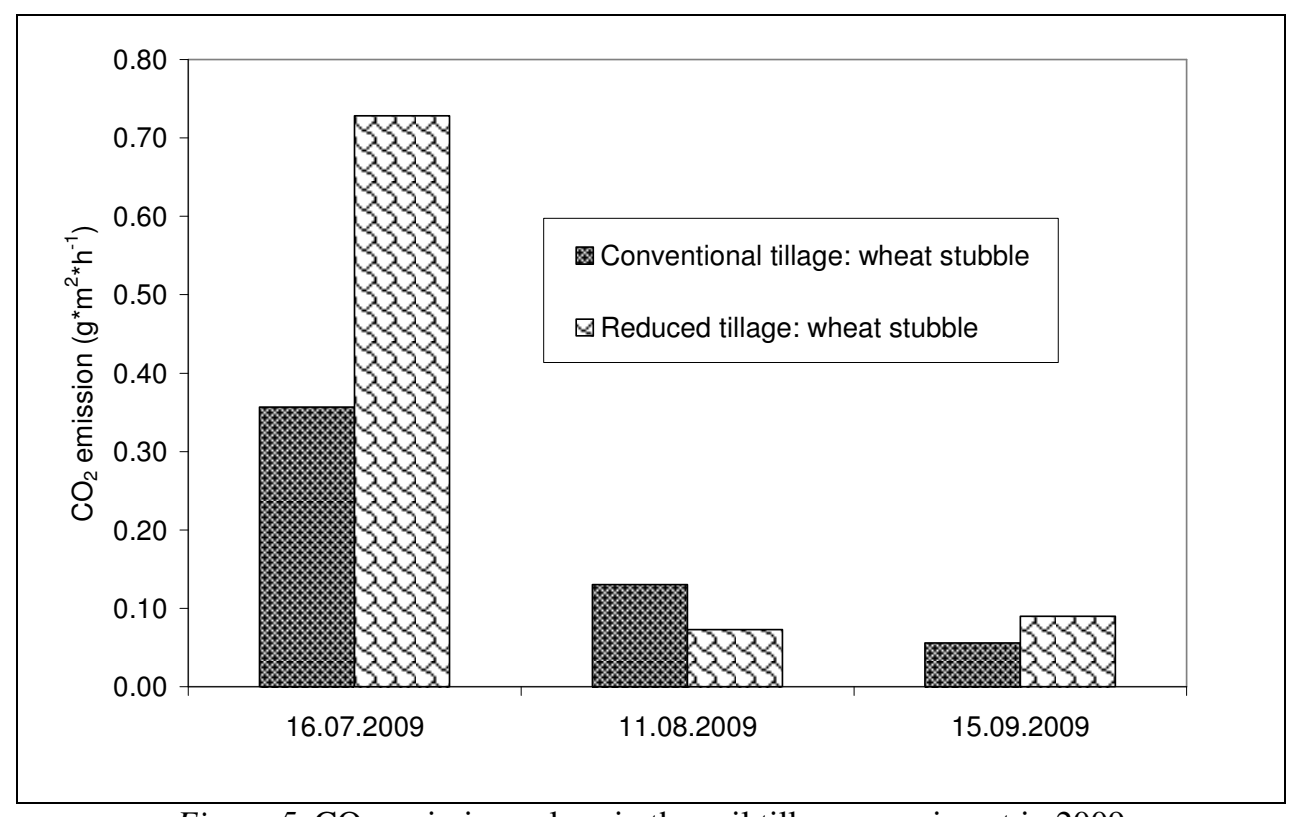

Figure 5. $\mathrm{CO}_{2}$-emission values in the soil tillage experiment in 2009

These results motivate us to continue our investigations. In normal years a peak of the microbiological activity is characteristic in autumn as the decomposition of plant residues is taking place if enough moisture is available. Experimental data provided information about 
the length of the time period when $\mathrm{CO}_{2}$ emission increasing effects of soil cultivation are observable.

\section{Conclusions}

There is close correlation between the degree and intensity of $\mathrm{CO}_{2}$-emission from the soil and the structural state and organic matter content of the soil. Applying alternative soil cultivation methods based on reduced disturbance of the soil more favourable conditions can be created in order to increase the organic matter content of the soil and the availability of the nutrients for the crops. Any disturbance by soil cultivation can partly mobilise the C-stock of the soil. The application of reduced cultivation supported the soil in approaching its natural equilibrium state. Under favourable soil moisture conditions microbiological activity (indicated by the level of $\mathrm{CO}_{2}$-emission) increased where reduced tillage system was applied. Studying the effect of different soil utilisation/cultivation methods on the $\mathrm{CO}_{2}$ emission from soil is indisputably actual and needs more efforts as it can contribute to develop a more environmental friendly agricultural production. These results motivate us to continue our investigations.

\section{References}

Birkás, M. - Kalmár, T. - Fenyvesi, L. - Földesi, P. : 2007. Realities and beliefs in sustainable soil tillage. Cereal Research Comm. 35. 2. 257-260.

Bolin, B.: 1981. Carbon Cycle Modelling. SCOPE 16, John Wiley \& Sons, Chichester.

Fieber, N.- Schimel, J.: 2003. A proposed mechanism for the pulse in carbon dioxide production commonly observed following the rapid rewetting of a dry soil. Soil Sci. Soc. Am. J. 67:798-805.

Franzluebbers, A.- Haney, R. - Honeycutt, C.- Schomberg, H. -Hons, F.: 2000. Flush of carbon dioxide following rewetting of dried soil relates to active organic pools. Soil Sci. Soc. Am. J. 64:613-623.

Gyuricza, Cs.: 2000. Az értékmegőrző és hagyományos talajművelés egyes fizikai és biológiai hatásának értékelése. Doktori értekezés. Gödöllö.

Holland, J. M.: 2004. The environmental consequences of adopting conservation tillage in Europe: reviewing the evidence. Agriculture, Ecosystems and Environment 103. 1-25.p.

NyiriI, L.: 1997. Az aszálykárok mérséklése, Mezőgazda Kiadó, Budapest.

Soulides, D. - Allison, F.: 1961. Effect of drying and freezing soils on carbon dioxide production, available mineral nutrients, aggregation, and bacterial population. Soil Sci. 91:291-298.

Trabalka, J.R., Reichle, D.E.:1986. The Changing Carbon Cycle; a Global Analysis. Springer-Verlag, New York.

Zsembeli, J. - Kovács, Gy.: 2007. Dynamics of CO2-emission of the soil in conventional and reduced tillage systems. Cereal Research Communications. Vol. 35. No. 2. 1337-1340

Zsembeli, J. - Tuba, G. - Kovács, Gy.: 2006. Development and extension of $\mathrm{CO}_{2}$-emission measurements for different soil surfaces. Cereal Research Communications. Vol. 34. No. 1. 359-362.

Zsigrai, Gy.: 2001. The Effect of Artificial Fertilization on Some Chemical Properties of The Soil and on The Yield of Maize in Long-Term Experiments. (In. Ed. LAZÁNYI, J.: Sustainable Agriculture and Rural Developement. Vider Plus Bt., Debrecen. 91-117.) 